\title{
Die noodsaaklikheid van habitat in ons definisie van menswees: Op soek na 'n eko-teologiese verstaan van menslike lewe
}

\begin{abstract}
Author:
Johan Buitendag ${ }^{1}$

Affiliation:

${ }^{1}$ Systematic Theology and Christian Ethics, University of Pretoria, South Africa

Note:

This article is the

dissemination of the author's registered research theme on 'understanding reality' and has formed the basis of a paper read at the ECST XIV Conference of the European Society for the Study of Science and Theology (ESSSAT) on 25 April 2012 in Tartu (Estonia).
\end{abstract}

\section{Correspondence to:}

Johan Buitendag

Email:

johan.buitendag@up.ac.za

Postal address:

Faculty of Theology,

University of Pretoria,

Pretoria 0002, South Africa

Dates:

Received: 20 June 2012

Accepted: 06 July 2012

Published: 26 Nov. 2012

How to cite this article: Buitendag, J., 2012, 'Die noodsaaklikheid van habitat in ons definisie van menswees: Op soek na' $n$ eko-teologiese verstaan van menslike lewe', HTS Teologiese Studies/ Theological Studies 68(1), Art. \#1283, 8 pages. http://dx.doi.org/10.4102/ hts.v68i1.1283

(C) 2012. The Authors. Licensee: AOSIS OpenJournals. This work is licensed under the Creative Commons Attribution License.
The indispensability of habitat in our definition of human personhood: In search of an eco-theological understanding of human life. The endeavour of this article is to arrive at a theological responsible conception of life. Life cannot be described adequately only in terms of body and soul (and/or spirit), or even in terms of human personhood. The point is that it is constitutive for life to take the human being's environment sociologically as well as ecologically into account. This article does not plead for a nature religion as advocated by the Deep Green Movement and all its variations of naturalism and supernaturalism, but asks for a revaluation of a Christian anthropology which approaches the Bible with a green hermeneutics. Perhaps the expression, 'bio-cultural' paradigm requests to be substituted with an eco-sociological niche of the human person. An eco-sociological (eco-theological) understanding of homo religiosus is therefore to assume human life as ontologically 'distributed'.

\section{Die uitdaging om lewe te definieer}

Om 'n definisie van lewe te verskaf, is 'n moeilike opgawe. 'n Mens staan omtrent voor dieselfde dilemma as wat Aurelius Augustinus (1997:168) ervaar het toe hy tyd wou definieer: 'Wanneer iemand my sou vra wat tyd is, weet ek; maar wanneer ek op sy vraag sou wou antwoord, weet ek nie.' Definisies oor die aard van lewe is dus nooit enkelvoudig nie, soos Singer (1994:111) tong in die kies daarop sinspeel: 'Life is a terminal disease, sexually transmitted!' So kan'n mens dan heeltemal onkant betrap word wanneer jy byvoorbeeld vrede sou hê met 'n gangbare definisie wat lewende organismes as 'self-constructing, self-maintaining, energy-transducing autocatalytic entities' (Weber 2011:11) beskou, net om die volgende oomblik tot die besef te kom dat hierdie einste definisie ook in 'n sekere mate op vuur van toepassing gemaak kan word! Vuur reageer inderdaad op eksterne kragte (soos byvoorbeeld wind), maar kan dit nie self reguleer nie. Indien voortplanting weer konstitutief vir lewe sou wees, verteenwoordig die muil, wat nie kan voortplant nie, skielik nie lewe nie!

Daar is dus twee uiterstes om te balanseer wanneer 'n mens na 'n gangbare definisie van lewe vra: enersyds die dinge wat ons as leweloos ag, maar wat tog binne die definisie pas (vuur) en andersyds die dinge wat ons lewend ag, maar wat weer buite die definisie val (muil). Dalk het Steven Potter (1986:3) 'n punt beet wanneer hy na die moontlikheid verwys dat lewe bloot 'man's perception of matter' is en dus geheel-en-al subjektief en per implikasie ondefinieerbaar is.

Hierdie artikel poog om by 'n Bybels-verantwoorde verstaan - nie soseer 'n definisie nie - van lewe uit te kom. Die artikel staan in 'n sekere sin voor dieselfde uitdaging as wat Jan Smuts ([1926] 1987) bykans honderd jaar gelede moes aanpak:

Matter, Life, and Mind, so far from being discontinuous and disparate, will appear as a more or less connected progressive series of the same great Process. And this Process will be shown to underlie and explain the characters of all three, and to give Evolution, both inorganic and organic, a fundamental continuity which it does not mean to possess according to current scientific and philosophical ideas. (bl. 21)

Sonder om holisme as sodanig onder die loep te neem, beredeneer ek dat menslike lewe nie toereikend in terme van slegs liggaam en siel (en/of gees) beskryf kan word nie. Meer nog, dat die mens selfs nie eers bevredigend as 'n menslike persoon gedefinieer kan word nie. Die term wat ek eerder voorstaan, is habitat of biotoop. Habitat behoort onlosmaaklik deel van ons antropologie te wees (Gregersen 2000). Ons moet uiteindelik by 'n eko-teologiese verstaan van menswees uitkom. Dit is dus konstitutief vir lewe om omgewing, sosiologies sowel as ekologies, te begryp. Vir ons teologiese verstaan van menswees, bepleit ek nie alleen die herontdekking van die biologiese wortels van die menslike persoon soos gemanifesteer binne 'n bio-kulturele nis nie, maar ook die erkenning van die verweefde omgewingseffek wat die wisselwerking tussen die genotipe en die fenotipe op die menslike persoon het. 
Moontlik illustreer die kwessie van die menslike embrio in die kliniese Petri-bakkie die gevaar van reduksie en die daaruit voortspruitende atomistiese verstaan van menswees, die beste. Is dit afdoende om te aanvaar dat ons reeds met ' $n$ mens te doen het die oomblik wanneer die sperm die oösiet binnedring? Ter opheldering: in die voorbereiding van ' $n$ kloningsprosedure word die DNS (deoksiribonukleïnesuur)draende kern uit die sitoplasma van verskillende oösiete gesuig en in ' $n$ ander se mitochondria geplaas. Deur middel van 'n elektriese impuls word ' $n$ fusie veroorsaak en die sel verdeel tot 'n volwaardige embrio. Aanvanklik word die verbinding eers as 'n kultuur in die laboratorium gekweek, waarna dit in die baarmoeder geplaas word om verder te ontwikkel (Buitendag 2004:404).

Ted Peters (2003:187) vra en antwoord tereg, 'What is in the Petri dish? A person? No, I do not think so.' Celia Deane-Drummond (2004:127) stem saam en oordeel dat die 'conceptus' 'n totaal ander status het as die fetus wat eers twee weke later gevorm word. Etici soos Peter Singer (1993:151) is dit ook hiermee eens en bestempel die klassieke beskouing se gebrek om hierdie onderskeid raak te sien en die mens van die begin as 'n persoon te beskou, eintlik as 'n 'shaky assumption' (Singer 1994:222). Verbasend genoeg het Herman Bavinck (1908:629) reeds aan die begin van die vorige eeu ewe 'gradualisties' geponeer dat die embrio geen volwaardige 'eigen $i k$ ' is nie! Deane-Drummond se huiwering om die embrio in die Petribakkie reeds ' $n$ menslike persoon te noem, illustreer presies die punt van my betoog: 'It downplays the importance of the environment' (Deane-Drummond 2006:145).

Dit bly egter 'n uitdaging vir die Teologie om interdissiplinêr en inklusief te dink. Wilson (2000:4) wys daarop dat die 'modern synthesis' van die sosiobiologie, die biologiese basis van álle sosiale gedrag aanvaar, maar betreur dit eweneens dat die Geesteswetenskappe ('humanities'), en ek voeg Teologie daarby, nog nie werklik hier aan boord gekom het nie. Gelukkig kom uitsonderings in hierdie verband al meer na vore, waaronder ek, onder andere, graag die Princetonteoloog, Wentzel van Huyssteen (2006), wil uitsonder.

\section{Kenteoretiese vooronderstellings}

Die teorie agter definisies is nie so voor die hand liggend as wat 'n mens dalk mag dink nie. Dit word allerweë aanvaar dat onderskei moet word tussen leksikale (stipulatiewe) en legislatiewe definisies (Gayon 2010:233). Eersgenoemde verduidelik die betekenis van 'n woord deur na die sogenaamde eintlike betekenis te verwys, terwyl laasgenoemde weer die omgekeerde doen en pertinente betekenis aan 'n woord toesê. Dit word arbitrêr gedoen en kan, maar hoef nie, een of meer van die betekenisvelde van die oorspronklike woord in die definisie opneem. Wetenskaplike definisies is merendeels stipulatief van aard.

Epistemologies is die teorie van definisies baie belangrik. Karl Popper (1966) wys daarop dat essensialisme die pretensie het dat die eintlike kern (aard) van 'n saak gevind kan word en dat dit gevolglik die taak van die wetenskap is om hierdie werklikheid aan te dui en te beskryf:
Instead of aiming at finding out what a thing really is, and at defining its true nature, methodological nominalism aims at describing how a thing behaves in various circumstances, and especially, whether there are any regularities in its behaviour. In other words, methodological nominalism sees the aim of science in the description of the things and events of our experience, and in an 'explanation' of these events, i.e. their description with the help of universal laws. (bl. 40)

Popper (2000) is boonop van mening dat die verskillende studievelde wat hulle vandag met lewe besig hou, nie deduktief vanaf sekere aannames behoort te vertrek nie, maar eerder induktief te werk moet gaan en toetsbare hipoteses daar moet stel wat die gedrag van verskynsels in sekere omstandighede probeer beskryf en verduidelik. Definisies het hiervolgens bloot 'n pragmatiese (verduidelikende) waarde. Popper (2000:18) gaan selfs so ver om te sê dat hy 'n weersin ('abhors') in definisies het en daarom eerder die begrip afleidings ('derivations') verkies (Popper 2000:33). Dit is dus nie 'n kwessie van wát of hoe iets is nie, maar eerder wat ons uit ons spesifieke waarneming kan aflei. Tog oordeel Jean Gayon (2010:238) dat die wetenskappe wat hulle met hierdie problematiek besig hou, gewis 'n behoefte het aan minstens 'n bepaalde terminologiese instemming ('unequivocal') oor wat onder lewe verstaan kan word, anders sal enige dialoog onbevredigend bly. Definisies is daarom nominalisties en die onderhawige vraag van hierdie artikel moet eerder wees wat ons as lewe sien en waarop ons dit begrond.

Die drie navorsingsvelde wat die afgelope aantal dekades as dominante gespreksgenote in die debat oor lewe uitgekristalliseer het, is die eksobiologie (vroeër astrobiologie), artifisiële lewe en die oorsprong van lewe. Die klassieke biologie is lankal nie meer die enigste wat oor lewe nadink nie. Vanweë die veelvuldigheid van gespreksgenote moet daar dus werklik gepoog word om by minstens ' $n$ 'definitional pluralism' in die dialoog uit te kom (Gayon 2010:238). Die teologie kan inderdaad met die begrip homo religiosus (Mircea Eliade) of homo transcendentalis ook hierin ' $\mathrm{n}$ bydrae lewer. 'At least we will all be talking about the same thing' (Keosian 1965:8).

Vanweë hierdie diversiteit is die 1968-uitgawe van die Encyclopaedia Britannica, 'Life', aangehaal deur Potter (1986:3) dalk heeltemal bruikbaar met sy voorstel dat '[ $t]$ here is no point along the continuum of existence from the simplest atom to the most complex animal, at which a line can be drawn separating life from nonlife'. John Keosian (1965:5-7) is insgelyks bewus van die wetenskap se dilemma om 'n doelmatige definisie te formuleer. Hy meen dat dit inderdaad haalbaar is om by iets sinvols in die gesprek uit te kom, mits 'n mens die futiele pogings om die presiese punt te bepaal waar materie na lewe oorgegaan het, laat vaar en jou eerder toespits op die omstandighede wat hierdie proses tot hoër vlakke van organisasie gevoer het.

\section{Filosofiese kontoere}

Teen bogenoemde agtergrond, is dit nodig om die argeologie van die verstaan van lewe duideliker te karteer. Dit blyk dat daar ' $n$ begripsontwikkeling plaasgevind het wat by 'n atomistiese of animistiese verstaan van lewe begin het. 
Dit is later meer dualisties of meganisties opgeneem en is uiteindelik as 'n proses of organisasie verstaan. Die grootste eksponente van genoemde drie lewensbeskouings is Aristoteles (384-322 v.C.), Descartes (1596-1650) en Kant (1724-1804) onderskeidelik.

\section{Atomisties}

In sy Filosofiese Lexicon (Boek $\Delta$ ) van die Metafisika het Aristoteles (1970:3-46) die boustene vir'n werklikheidsverstaan geïdentifiseer. Anders as Plato het hy nooit die siel van die liggaam losgemaak nie. Die siel is weliswaar ' $n$ vorm van die liggaam, maar nooit so dat dit onafhanklik in 'n ander domein kan bestaan nie. Aristoteles wil in hierdie kosmos leef en dink. Dit het hom gelei tot die onderskeid tussen potensialiteit en aktualiteit. Die wesenskenmerk van 'n saak is dus die vermoë om te kan verander. Dit beteken dat 'n vorm by Aristoteles reeds ' $n$ telos [eindpunt] in sigself huisves (entelegie). Indien dit nie daarin voorkom nie, is dit suiwer materie: vuur, water, lug of grond. Dit is ook die verskil tussen klei en 'n baksteen: klei is die materie van 'n baksteen en 'n baksteen is die vorm van klei. Hierdie vorm (eintlikheid) is vir Aristoteles substansie in die volle sin van die woord. Die wetenskap se taak is juis om definisies te verskaf, want dit is die wesenlike van alles (Aristotle 1970:18).

Aristoteles meen daar is 'n hiërargie in die syn. Namate die lyn styg, kom aktualiteit meer tot sy reg en verwesenlik dit vorm. Hierdie hiërargie verloop soos volg: plante $\rightarrow$ diere $\rightarrow$ mense (met bewussyn). Elke trap integreer die vorige se wesenseienskappe ten volle, maar is tegelykertyd ook 'n verbetering daarop. Die mens is nie siel én liggaam nie, maar 'n enkelvoudige substansie. Die nous van die mens los eers op in die dood.

In sy studie oor Aristoteles se verstaan van lewe, toon James Lennox (2001:100) aan dat dit vir Aristoteles duidelik was dat bioloë hulle onderwerp nooit los van materie kan bestudeer nie, want natuur behoort altyd teleologies beskou te word en dit is daarom noodsaaklik om die relasie tussen potensialiteit en aktualiteit te beskryf.

\section{Dualisties}

Dit is moontlik om hierdie lewensbeskouing na analogie van William Paley (2006:7-8) se horlosie-voorbeeld te verduidelik en die werklikheid as 'n fyn, meganiese ontwerp te sien. Die woorde van Richard Dawkins (2006) se sinspeling daarop is baie duidelik: The blind watchmaker! Die werklikheid is dus onafhanklik van enige metafisiese ingreep en stu meganisties voort. Die implikasie hiervan is dat die woord lewe toenemend onderwaardeer word en uiteindelik selfs vermy word. Descartes, die vader van hierdie denke, gebruik die beginsel van volstrekte twyfel om alle skynsekerhede van sintuiglike waarneming te ontmasker. Die inisiatief om tot die kern van waarheid deur te dring, gaan nie van die wêreld af uit nie, maar van die mens self. Die menslike rede is uiteindelik die as waarom alles wentel (Descartes 1965:88). Dit moet egter nie so verstaan word dat die waarheid in die fisiese wêreldbetrokkenheid geleë is nie, maar wel in die eensaamheid van die menslike bewussyn, die cogito ergo sum. Dit is ook nie die resultaat van die denke oor die syn nie, maar die onmiddellike selfkennis van die bewussyn wat die denke nie kan negeer nie. Slegs dit wat ek nou 'helder en duidelik' kan begryp, is waar. In soverre die werklikheid nou uitgebreid is en kwantifiseerbaar is, is dit ook waar. 'n Abstrakte dualisme van subjek en objek, gees en natuur, vloei gevolglik hieruit voort.

Peter Singer (1994:168) argumenteer tereg dat Descartes slegs aan die mens 'n onsterflike siel toedig en die mens daarom oor ' $n$ bewussyn beskik, anders as diere. Hoewel diere meer ingewikkeld as meganika saamgestel is, is hulle in der waarheid slegs uiters komplekse masjiene. Soos wat 'n horlosie 'n geluid kan maak, kan diere ook, maar dit beteken steeds nie dat hulle 'n bewussyn besit nie. Met die ontwikkeling van die chemie sedert die agtiende eeu, het dit toenemend mode geword om lewe in terme van chemiese materiaal en meganisme te beskou (Weber 2011:2).

\section{Prosesmatig}

Lewe word in hierdie lewensopvatting as organismies beskou. Dit het selfs 'n tipe dialektiese 'derde opsie' geword tussen die animistiese en die meganistiese uitgangspunte van die vorige twee paragrawe. Miskien is die beeld van vuur om sellulêre metaboliese aktiwiteit te vergelyk, tog nie so vergesog nie! Die voorwaarde is egter dat hierdie 'pattern of chemical processes' (Haldane 1947:56) nie bloot tot 'n meganisme of fisikalisme gereduseer mag word nie.

Dit is vir Kant - die eksponent hiervan - duidelik dat niks sonder ' $n$ doel kan bestaan nie en dat biologie alleen in terme van ' $n$ intrinsieke teleologie beskryf kan word (Ruse 2008:72). Kant se bekende uitspraak dat die mens nie 'n middel tot ' $n$ doel is nie, maar ' $n$ doel op sigself (Paton 1972:32), dui natuurlik reeds op hierdie onderskeid tussen gewone lewe en menslike lewe en die sentrale plek wat die mens in die natuur beklee. Dit gee aan die mens ook 'n besondere verantwoordelikheid. 'n Soort 'regulative principle' of imperatief is dus noodsaaklik.

\section{Biologiese kontoere}

Benewens die fisies-chemiese basis vir die verstaan van lewe, is dit noodsaaklik dat daar ook na die Darwiniaanse ontwikkeling gekyk moet word. NASA, wat baie van hulle navorsing op die ontdekking of verstaan van lewe rig, ag dit wesenlik in hulle definisie oor lewe (Gayon 2010:234). Die jongste weergawe van die Encyclopaedia Britannica (2012) val hierby in en formuleer kort en kragtig: 'A genetic definition of life therefore would be a system capable of evolution by natural selection.' Dit is duidelik dat replikasie 'n belangrike komponent van hierdie definisie uitmaak. Dit beteken dat die DNS, anders as voortplanting wat nuwe generasies tot gevolg het, dit self noukeurig kopieer. Dit is die rede waarom Charles Darwin duidelik onderskei het tussen die oorsprong van lewe (The origin of species [1859] 1999) en die afkoms van lewe (The descent of man - [1879] 2004). Lewe word as 'n gegewe beskou en deur kombinasies van toeval en noodwendigheid kom nuwe mutasies tot stand. 
Die geofisiese omstandighede van planeet aarde se eerste oomblikke was heelwat anders as vandag en 'n tipe oersop van organiese molekules het tot lewe gelei. Die gevolgtrekking wat Keosian (1965) hieruit maak, is belangrik vir ons argument:

A gene by itself ('in vacuo', so to speak) is meaningless. It has meaning only in relation to the phenotype which it determines. If a gene was indeed the first expression of life, its minimum phenotype was the very nature of this restricted environment, which must be separate from the surrounding medium. (bl. 70)

Alhoewel Weber (2011:10) oordeel dat hierdie oorgang na lewe uiters belangrik is, val die fokus van hierdie artikel eerder op die interaksie met die omgewing. Hierdie filogenese open nuwe perspektiewe op die verstaan van die werklikheid, soos Wildman (2009) dit treffend uitdruk:

On this road, we celebrate the discovery of the network of ecological relationships that suffuses our lives, historically and bodily, and we become increasingly intentional about habitat engineering projects to relieve suffering, increase justice, and to enjoy the possibilities that life presents. (bl. 203)

\section{Molekulêre biologie}

Aan die begin van die twintigste eeu het Sir Frederick Gowland Hopkins, die eerste professor in Biochemie aan die Universiteit van Cambridge, vitalistiese sowel as meganistiese reduksionisme verwerp. Hy soek die oplossing eerder in 'n molekulêre benadering tot lewe waar die sel soos ' $n$ chemiese masjien funksioneer wat die beginsels van fisiese chemie en termodinamika onderskryf. Dit moet egter sodanig wees dat dit georganiseerde molekulêre strukture en funksies het:

The living cell is not a mass of matter composed of a congregation of like molecules, but a highly differentiated system: the cell, in the modern phraseology of physical chemistry, is a system of coexisting phases of different constitutions. (Hopkins aangehaal in Weber 2010:222 \& 2011:4.)

Geïnspireer deur Alfred North Whitehead het Hopkins die klem gevolglik eerder op prosesse as op entiteite laat val. Erwin Schrödinger, wie se navorsing groot invloed op Francis Crick, James Watson en ander gehad het, verdien veral vermelding. Hy het gepoog om die kwantumfisika diensbaar te maak in die soeke na 'n definisie van lewe. Sy boek What is Life? ([1944] 1967), is gebaseer op lesings wat hy gedurende Februarie 1943 by die Trinity College in Dublin gelewer het. Enersyds gaan dit vir hom oor die waarneming dat bestaande orde voortduur en selfs verdere orde voortbring; en andersyds oor die kwessie hoedat orde weer uit wanorde voortspruit. Die oplossing wat Schrödinger bied, lê in die wisselwerking tussen 'n organisme en dié se betrokke omgewing. (Die Griekse woord vir die tipe metabolisme wat hier plaasvind, dui juis op die uitruil van stof.)

Absolute zero $\left(-273{ }^{\circ} \mathrm{C}\right)$ is byvoorbeeld die punt waar die entropie van enige substansie nul is en die maksimum entropie of termodinamiese ekwilibrium bereik is. Alle aktiwiteit in die natuur laat die entropie styg en bring dit nader aan hierdie absolute punt, wat die dood is. Hierdie energie kan natuurlik slegs vanaf die omgewing kom en dit word negatiewe energie genoem. Daar bestaan dus 'n omgekeerde eweredigheid. Soos wat die energie van 'n substansie verhoog, verlaag die energie van die omgewing en andersom. Entropie én negatiewe entropie is dus noodsaaklik vir balans (Schrödinger [1944] 1967:73-80).

'n Mens het weliswaar hier met 'n argument uit die Fisika te maak om lewe te verduidelik, maar die waarde hiervan is nie soseer om die onbepaalbaarheid van die grens tussen lewe en materie aan te toon nie, maar wel om die belang van die omgewing (habitat of biotoop) as konstitutief vir alle bestaan aan te dui! Deur die uitruil van energie word lewe gekontinueer en die fatale toestand van ekwilibrium afgeweer. Francis Crick (1966:10) kan dus konkludeer: 'The ultimate aim of the modern movement in biology is in fact to explain all biology in terms of physics and chemistry.' Arthur Peacocke (2004:41) uiter egter 'n gepaste woord van waarskuwing in hierdie verband, naamlik dat daar nie iets soos grade van werklikheid is nie. ' $n$ Atoom is byvoorbeeld nie meer werklikheidsgetrou as 'n sel nie.

\section{Fenotipiese plastisiteit}

Erwin Schrödinger het weliswaar 'n meer meganiese aanpak in sy verstaan van lewe gehad. Tog het die Tweede Wet van die Termodinamika hom sensitief gemaak vir die verhouding tussen die genotipe en die fenotipe as bepalend vir lewe (Potter 1986:4). Terwyl die genotipe'n organisme se volledige genetiese inligting bevat, manifesteer die fenotipe weer die morfologiese eienskappe (McGrath 2005:40). Die genotipe en die fenotipe staan natuurlik nie in 'n een-tot-eenverhouding met mekaar, asof bepaalde fenotipiese eienskappe geneties gekodeer is nie (Buskes 2008:41). Twee geneties-identiese organismes kan vanweë omgewingsfaktore heeltemal verskillend ontwikkel. Hierdie 'speelruimte' van die organisme noem bioloë die 'fenotipiese plastisiteit'. Dit is met ander woorde die mate waartoe 'n organisme se fenotipe deur ander faktore as bloot die genotipe bepaal word. Anders gestel: dit is 'n organisme se vermoë om sy fenotipe aan te pas na gelang van verandering in sy omgewing.

Richard Dawkins het in sy boek, The selfish gene (1989), die geen as die eintlike bousteen ('diamond') vir die werklikheid aangebied en dit as deurslaggewend vir die organisme se fenotipe beskou (Dawkins 1989:35). Dit kom kortliks daarop neer dat die gene in die evolusieproses geselekteer word en nie die objek van instruksie is nie. Daarom praat Dawkins (1982) van die geen as 'n uitgebreide fenotipe ('extended phenotype'). Dit beteken dat die gene nie net die individuele organisme bepaal nie, maar ook die groter omgewing van die organisme beïnloed. Die individu is in werklikheid dus 'a survival machine built by a short-lived confederation of long-lived genes' (Dawkins 1989:44). Analoog aan genetiese replikatore (gene), skep Dawkins die verwante konsep van meme as kulturele replikatore (Dawkins 1989:192). Meme is die resultaat van genetiese instruksies. ${ }^{1}$

1.Alister McGrath (2005:125) het sterk teen hierdie teorie van Dawkins beswaar gemaak en dit as'n gedagtekonstruk afgemaak wat nie net oorbodig is nie, maar ook onwetenskaplik. 
Hier beweeg die biologiese en geesteswetenskappe nader aan mekaar. Volgens Habermas (1993:90-108) is daar 'a close relationship between communicative rationality and the life world or "Lebenswelt"' en is die:

... life world not only the background to the communication process, but also the source from which the participants can draw common understandings and values. The concept of life world is thus complementary to the concept of communicative actions. Without the background of a shared life world, discourses about validity claims (truth, rightness, truthfulness) are impossible. (Habermas 1979:118-120)

Teenoor 'n bepaalde dominansie van die genotipe het Stephen Jay Gould sterk standpunt ingeneem. Vir Gould (1986:20) is dit duidelik dat gene muteer, individue geselekteer word en spesies evolueer:

Richard Dawkins would narrow the focus of explanation even one step further-to genes struggling for reproductive success within passive bodies (organisms) under the control of genes-a hyper-Darwinian idea that I regard as a logically flawed and basically foolish caricature of Darwin's genuinely radical intent. (Gould 1997:3)

Gould (1986) stel dit dat die fenotipe en nie die genotipe nie, die voorwerp van natuurlike seleksie is:

No matter how much power Dawkins wishes to assign to genes, there is one thing that he cannot give them - direct visibility to natural selection. Selection simply cannot see genes and pick among them directly. (bl. 24)

Die voertuig vir seleksie is, volgens Gould, die fenotipe, juis omdat die fenotipe met die omgewing in ' $n$ wisselwerking staan as gevolg van natuurlike seleksie. Die gene veroorsaak dus nie evolusionêre veranderings nie, hulle registreer dit bloot. Benewens natuurlike seleksie wil Gould dus ook erkenning verleen aan die historiese en morfologiese prosesse van die omgewing.

Hoe dit ook al sy, die debat van nature versus nurture (dalk gebore teenoor getoë?) maak wel duidelik dat nóg die genotipe, nóg die fenotipe alleen individuele variasie veroorsaak en dat nagenoeg alle eienskappe van spesies sowel genetiese as omgewingsfaktore veronderstel. Matt Ridley is dus reg om nie die natuur versus op/voeding te stel nie, maar wel die natuur via op/voeding (gebore én getoë): 'I believe human behaviour has to be explained by both nature and nurture' (Ridley 2003:3).

\section{Oikos - 'the home of all the family of the universe $^{2}$}

Volgens Arthur Peacocke (2004:41) is daar geen beter argument om ' $n$ bepaalde reduksionisme in die verstaan van lewe af te weer nie as juis om die ekologie in berekening te bring: 'For ecology is the study of the interdependence of all living forms within their physical, organic and social environment.' Elke ekosisteem bestaan uit 'n spesifieke aantal lewende organismes in wisselwerking met hulle omgewing (Burnie 1994:168). Die term ekologie is afgelei van die twee Griekse woorde 'oikos' wat huis beteken en 'logos' wat studie beteken. 2.Aanhaling van Jan Smuts ([1926] 1987:343).
Ekologie behels dus die studie van lewende organismes (die mens ingesluit) en hulle habitat asook die wedersydse wisselwerking daartussen (Maarschalk 2001:1).

Die omgewing wat organismes huisves, staan bekend as 'n biotoop. Dit het altyd bepaalde fisiese, chemiese en biologiese eienskappe en is dus sowel organies as anorganies. Die eenheid wat tussen die biotoop en die organismes bestaan, staan bekend as 'n ekostelsel. 'n Legio faktore binne sowel as buite die ekostelsel bepaal die unieke aard daarvan. Die lewensgemeenskap van die biotoop stel voortdurend eise wat vir sy voortbestaan deurslaggewend is. 'n Ekostelsel vorm met ander woorde ' $\mathrm{n}$ min of meer geslote stelsel van organismes wat deur interaksie 'n dinamiese ewewig na binne en 'n bepaalde stabiliteit na buite handhaaf.

Sedert die negentigerjare van die vorige eeu het 'n nuwe interpretasie van die biotoop in Engeland gevestig geraak wat oordeel dat die biotoop = habitat + gemeenskap (Ducrotoy 2011:2). Dit impliseer dat die biotoop juis die omgewingsfaktore wat die habitat uitmaak, absorbeer. Daarom kan biodiversiteit juis as die verskeidenheid van spesies in 'n spesifieke omgewing beskryf word (Burnie 1994:176). Sodanige biodiversiteit kan natuurlik tussen verskillende habitats wissel.

Die implikasie hiervan is dat die biotoop met ander vlakke van biodiversiteit koppel en die verskillende funksies integreer. Hierdie sisteembenadering van die filogenetika impliseer die volgende vooronderstellings ten opsigte van die biotoop: dit is 'n komponent van ekosisteme; dit het ruimtelike kontoere; dit besit historiese ontwikkeling; dit vorm deel van groter prosesse; en het ook natuurlike vyande (Ducrotoy 2011:4). Wildman (2009) lewer ' $n$ groot bydrae om habitat deel van die antropologie te maak en die mens op voetspoor van Schleiermacher (en Eliade), as 'n homo religiosus te beskryf:

Surely, one of the most neglected themes in religious anthropology is the location of human beings in the context of the microbial ocean that births, supports, threatens, and reabsorbs them. (p. 174)

\section{Teologiese kontoere}

Lynn White hou in sy artikel in die opsienbare natuurwetenskaplike tydskrif, Science, die Judaïes-Christelike godsdienste mede-aanspreeklik vir die ekologiese krisis wat sedert die sestigerjare wêreldwyd al hoe duideliker begin manifesteer het. Die rede vir hierdie aandadigheid is die betrokke godsdienste se dogmas oor die skepping! Die mens is as heer en meester van die natuur gewaan: 'Hence we shall continue to have a worsening ecologic crisis until we reject the Christian axiom that nature has no reason for existence save to serve man' (White 1996:193). Na die Middeleeue het begrippe soos wetenskap en tegnologie heilige status begin geniet omdat dit juis die mens se dominansie oor die natuur duidelik illustreer (White 1996:191).

'n Voorbeeld waar die Christendom die prestasies van hierdie tegniese voortuitgang vir sigself wil toeëien, is te vind in die werk van Friedrich Gogarten (1957). Sekularisasie 
is vir hom goed, want dit bepaal die verhouding tussen geloof en rede en voorkom dat geloof slegs 'n aangeplakte kontemplasie by redelike feite is. Sekularisasie is die legitieme vrug van die Christendom; die Christendom het die mens selfstandig gemaak, aldus Gogarten (1957:8). Aangesien die grondoorsaak van die probleem by godsdiens lê, betoog White, sal die oplossing ook daar gesoek moet word en hy smag gevolglik na die opkoms van 'n nuwe godsdiens. Hy verlang na die eenheid wat Franciscus van Assisi met die natuur gehad het. 'I propose Francis as a patron saint for ecologists' (White 1996:193).

Lynn White se versugting het nie op dowe ore geval nie. Terwyl die ekologiese probleem aanvanklik, met enkele uitsonderings na, slegs eties hanteer is, begin die ingewydes die verweefde rypheid van die debat terdeë ontdek. Vermeldenswaardig is die stemme wat spesifiek uit die feministiese denke kom en ekologies kontoere aanneem, byvoorbeeld dié van Wainwright (2010), Deane-Drummond (2008), Tanner (1988), McFague (1993), Howell (2000) en vele ander. Die doyenne-eksegeet van die ekologiese interpretasie van Bybelse tekste, Elaine Wainwright, ontleen die konsep habitat van Lorraine Code wat dit soos volg verstaan:

As a place to know where social-political, cultural, and psychological elements figure alongside physical and (other) environmental contributors to the nature of a habitat and its inhabitants at any historical moment. (Wainwright 2010:160.)

Wat verder groot vreugde verskaf, is dat Bybelwetenskaplikes soos Norman Habel en Peter Trudinger die Bybel nou met 'n ekologiese hermeneutiek begin lees en die Stem van die Aarde in eksegese laat meespreek.

En die opkoms van 'n nuwe godsdiens waarna White so gesmag het? In 2010 verskyn 'n boek met die titel Dark green religion (Taylor). Dit gaan nie net om 'n groen bewussyn nie, maar inderdaad om 'n werklike groen godsdiens: 'Dark green religion is generally deep ecological, biocentric, or ecosentric, considering all species to be intrinsically valuable, that is, valuable apart from their usefulness to human beings' (Taylor 2010:13).

'n Ekologiese hermeneutiek laat 'n mens ook onmiddellik die klassieke interpretasie van Bybelgedeeltes dekonstrueer. Die skeppingperikoop van Genesis 1:1-2:4 asook die interpretasie van die wysheidsliteratuur is voorbeelde hiervan. Vandag besef ons dat Genesis 1:28 se 'onderwerp en heers daaroor', geen outoritêre dominansie in die oog het nie, maar gewoon 'n voedselgebod vir die mens is (Liedke 1983:132). Die diere eet gras en blare, maar die mens kry saad en vrugte wat bepaalde handearbeid verg (Gen 1:29, 30). Geen wonder nie dat hedendaagse vertalings eerder 'bewoon en bewerk' verkies.

'n Mens sou ook voorbeelde uit die wysheidsliteratuur kon bekyk: die mens deel dieselfde lot as die dier (Pred 3:19) en sterf soos elke ander kreatuur (Job 14); die regverdige en sy diere is wedersyds afhanklik van mekaar (Spr 12:10) en 'vlees' is tegelykertyd 'n antropologiese en 'n kosmologiese begrip (Ps 90). 'En so word die begrip "medemenslikheid" na "medekreatuurlikheid" verander en word die lewe die kleinste gemene deler van die skepping' (Buitendag 2004:414).
Die bekende skeppingperikoop van Genesis 1:1-2:4a laat die mens se verweefdheid met die natuur duidelik blyk. Dit is belangrik om Genesis 1 vanuit 'n tyd-ruimtelike perspektief te lees. Dit is bekend dat hierdie verhaal gedurende die ballingskap geskryf is. Die priester-digter hanteer deurgaans tyd en ruimte. Die verhaal begin nie by die wegvoering van die Suidryk (586 v.C.) nie, maar 'in die begin'. Hy skryf sy verhaal van die eerste oomblik af. Hierdeur gebruik hy tyd as die matrys van die skepping: dag en nag, ses dae plus die sewende dag, maar hierdie keer sonder 'n nag. Die God van Israel is van ewigheid af God en sal tot in ewigheid ook God wees. Die priester hanteer ook die ruimtelike aspek: soos kleiner-wordende sirkels ontplooi hy sy verhaal: lig, lug, grond en plante is die formele aspekte van die eerste drie dae, waarop die bewoners daarvan die laaste drie dae volg: voëls, visse, diere en mense. 'n Mens hoor selfs 'n bepaalde indeling uit die ekologie: die eksosfeer $\rightarrow$ atmosfeer $\rightarrow$ hidrosfeer $\rightarrow$ troposfeer $\rightarrow$ biosfeer. Teologies kan die mens hom- of haarself nie van hierdie partisiperende nis loswikkel nie!

Hierdie perikoop vorm 'n soort inclusio met verse 1:1 en 2:4a wat dieselfde uitdrukking aan die begin en aan die einde het: hemel en aarde wat God geskep het. Die hoogtepunt van die skepping is dus nie die mens nie, ook nie eers dag ses nie, maar wel dag sewe, die Sabbat. Dit is wanneer God en mens vreedsaam in die skepping verkeer en waarna ons steeds reik. Cas Labuschagné (1991) stel onomwonde dat ons in die Bybelse skeppingstekste nooit die mens in die sentrum vind nie, maar wel Gód. Na aanleiding van Kolossense se kosmiese versoeningsperikoop (1:15-20) voeg hy by dat versoening waarskynlik ekosentries opgeneem moet word, maar indien nie, minstens biosentries (Labuschagné 1991:131).

\section{Gevolgtrekking 'n Eko-teologiese lewensbeskouing}

Spraakverwarring herinner altyd aan die saga van die Toring van Babel. Op grond van navorsing wat Palyi gedoen het, wys Gayon (2010:240) daarop dat daar ongeveer 40 verskillende definisies van lewe onder wetenskaplikes bestaan. Uit hierdie definisies is dit duidelik dat sommiges die klem op komponente plaas, ander weer op verbindings, nog ander op termodinamiese eienskappe - hetsy op reproduksie en replikasie, op sisteme, of (en dit is belangrik) op 'n kombinasie van al hierdie elemente.

'n Goeie voorbeeld hiervan is die definisie van NASA se Eksobiologiese Program, naamlik 'Life is a self-sustained chemical system of undergoing Darwinian evolution' (Gayon 2010:234). Hierdie spesifieke verwysing na Darwiniaanse evolusie val vreemd op die oor, omdat dit 'n definisie binne 'n definisie is wat alreeds ' $n$ veronderstelling impliseer in die saak wat beskryf word. Waarskynlik ontkom hierdie definisie ook nie heeltemal aan 'n bepaalde vorm van essensialisme nie. Die boustene van 'n chemiese sisteem (soos molekules, membrane, ens.) word immers implisiet in die definisie veronderstel. Tog is die dinamiese en funksionele aspekte van die definisie te verwelkom. Die Stanford Encyclopedia of Philosophy (Weber 2011:8) is dus korrek wanneer dit in terme 
van lewe, die klem op die eko-relasionele beskrywing lê en gevolglik nie na lewe as sodanig vra nie, maar eerder na die omgewing (habitat) van lewe. Ek wil Wildman (2009:181, 2010:165) se stelling gekwalifiseerd onderskryf: 'Human beings are a walking, feeling, thinking superorganism, an entire mobile ecology of organisms.' Hoewel dit die ekologie behoorlik in die definisie verdiskonteer, doen dit steeds afbreuk aan die mens se partiserende deelname aan die (groter) habitat.

Die konsep van die menslike persoon het weliswaar die dualisme van liggaam-siel/gees oorkom, maar ongelukkig nie die ekologiese bedding toereikend verreken nie. George Lindbeck (1984) met sy 'sosiolinguistiese' nis vertoon dieselfde tekortkoming. Natuurlik is die mens ' $n$ relasionele wese - daaroor stem die verskillende wetenskappe saam - maar die netwerk is sosiologies sowel as ekologieste omskryf. Selfs die term bio-kulturele paradigma, het bepaalde tekortkomings. Die wisselwerking binne en met die habitat, wat op sy beurt deel van 'n grotere ekostelsel uitmaak, ontsnap helaas die gesigveld van die term.

Wesley Wildman (2010:165) bepleit 'n spirituele naturalisme om by ' $n$ omvattende verstaan ('distributed identity') van menswees uit te kom. Tereg soek hy dan ook aansluiting by Eliade se homo religiosus (Wildman 2009:211):

The new road brings vistas of ultimate reality lying within the axiological depth structures and dynamics of nature - and not just a convenient selection of them that reinforces our realityevading biases toward the pleasant of our alienated biases toward the unpleasant, but nature as a whole. (Wildman 2009:203.)

Ek bepleit geensins ' $n$ natuurgodsdiens soos voorgehou deur die Diepgroen Beweging met sy variasies van naturalistiese en supra-naturalistiese perspektiewe op animisme nie, maar vra vir ' $n$ herwaardering van die Christelike antropologie wat met'n groen hermeneutiek die Bybel benader. So belangrik as wat 'n gunstige habitat of biotoop vir die mens is om te oorleef, te gedy en te evolueer, so belangrik is dit ook om ' $n$ bepaalde waardesisteem vir die verstaan van menswees te konsipieer.

Ek ondersteun graag pogings soos dié van Celia DeaneDrummond wat op ' $n$ induktiewe wyse die aksiologiese kwaliteite van die natuur ondersoek en met religieuse simbole probeer uitdruk. Die waarde-dimensie van die menslike habitat verg nie alleen ondersoek nie, maar ook die kreatiewe daarstelling en uitlewing daarvan. Dit sluit nó aan by die latere Habermas (2008) se opmerking oor die rol en verantwoordelikheid van teologie ten opsigte van die definiëring van lewe:

Religious traditions have a special power to articulate moral intuitions, especially with regard to vulnerable forms of communal life. In corresponding political debates, this potential makes religious speech into a serious vehicle for possible truth contents, which can then be translated from the vocabulary of a particular religious community into a generally accessible language. However, the institutional thresholds between the 'wild' political public sphere and the formal proceedings within political bodies also function as a filter that allows only secular contributions from the Babel of voices in the informal flows of public communication to pass through. (bl. 131)
Die slotakkoorde van Darwin se Origin of species ([1859] 1999) is nie net digterlik indrukwekkend nie, maar wetenskaplik en teologies tog so waar (veral as 'n mens besef dat hy aanvanklik in die eerste uitgawe van 1859, On the origin of species, die 'by God' ingevoeg gehad het):

There is a grandeur in this view of life, with its several powers, having been originally breathed in to a few forms or in to one [by God]; and that, whilst this planet has gone cycling on according to the fixed law of gravity, from so simple a beginning endless forms most beautiful and most wonderful have been, and are being, evolved. (bl. 400)

Dalk vra die uitdrukking 'bio-kulturele' paradigma, wat ESSSAT (European Society for the Study of Science and Theology) met sy sewende kongres in 1998 in Durham, Engeland, voorgestel het, om die menslike persoon in al sy of haar uitdrukkingsvorms te beskryf (Gregersen, Drees \& Görman 2000:6), en te vervang met 'n eko-sosiologiese of eko-teologiese nis van die menslike persoon. Dit transendeer die atomisme van die Petribakkie en resoneer aan Jan Smuts se holisme. 'n Eko-sosiologiese verstaan van homo religiosus impliseer dus om die menslike lewe as ontologies uitgebreid te verstaan.

\section{Erkenning}

Ek dra hierdie artikel ook graag op aan my kollega, professor Pieter Venter, met sy emeritaatsaanvaarding. Die 32 jaar wat hy in diens van die Universiteit van Pretoria was, het hy 'n substansiële bydrae tot teologiese navorsing gemaak en wye erkenning in sy nis deur vakgenote geniet.

\section{Mededingende belange}

Die outeur verklaar dat hy geen finansiële of persoonlike verbintenis het met enige party wat hom nadelig kon beïnvloed in die skryf van hierdie artikel nie.

\section{Literatuurverwysings}

Aristotle, 1970, Aristotle's 'Metaphysics', Everyman's Library, London.

Augustinus, A., 1997, 'The Confession sand letters of St Augustin with a sketch of his life and work', in The Nicene and Post-Nicene Fathers, p. 168, Logos Research Systems, Oak Harbor, WA.

Bavinck, H., 1908, Gereformeerde Dogmatiek, Kok, Kampen.

Buitendag, J., 2004, 'Anders dink anders doen: Op soek na 'n eko-teologiese perspektief op kloning', Verbum et Ecclesia 25(2), 402-422.

Burnie, D., 1994, Concise Encyclopedia: Nature, Dorling Kindersley, London.

Buskes, C., 2008, Evolutionair denken: De invloed van Darwin op ons wereldbeeld, Uitgeverij Nieuwezijds, Amsterdam.

Crick, F., 1966, Of molecules and men, University of Washington Press, Seattle, WA.

Darwin, C., [1859] 1999, The origin of species, Bantam Books, New York, NY.

Darwin, C., [1879] 2004, The descent of man, Penguin Books, London.

Dawkins, R., 1982, The extended phenotype, Oxford UniversityPress, Oxford.

Dawkins, R., 1989, The selfish gene, Oxford University Press, Oxford.

Dawkins, R., 2006, The blind watchmaker, Penguin Books, London.

Deane-Drummond, C., 2004, The ethics of nature, Blackwell Publishing, Oxford. http://dx.doi.org/10.1002/9780470773451

Deane-Drummond, C., 2006, Genetic sand Christian ethics, Cambridge University Press, Cambridge.

Deane-Drummond, C., 2008, Eco-theology, Darton, Longman \& Todd, London.

Descartes, R., 1965, A discourse on method: Meditations and principles, Everyman's Library, London.

Ducrotoy, J-P., 2011, 'Biotopes and classification systems' in, Coastal Wiki, viewed 27 January 2012, from http://www.coastalwiki.org/coastalwiki/Biotopes_and classification_systems 
Encyclopaedia Britannica, 2012, "Life", viewed 23 February 2012, from http://0-www. britannica.com.innopac.up.ac.za/EBchecked/topic/340003/life

Gayon, J., 2010, Defining life: Synthesis and conclusions, Sorbonne, Paris.

Gogarten, F., 1957, Verhängnis und Hoffnung der Neuzeit: Die Säkularisierung als theologische Problem, Vorwerk, Stuttgart.

Gould, S.J., 1986, 'Caring groups and selfish genes', Natural History 86(12), 20-24.

Gould, S.J., 1997, 'Darwinian Fundamentalism', in The New York Review of Books, viewed 24 February 2012, from http://www.nybooks.com/articles/archives/1997/ jun/12/darwinian-fundamentalism/

Gregersen, N.H., 2000, 'Varieties of personhood: Mapping the issues', in The Human Person in Scienceand Theology, pp. 1-17, Clark, Edinburgh.

Gregersen, N.H., Drees, W.B. \& Görman, U., 2000, The human person in science and theology, Clark, Edinburgh.

Habermas, J., 1979, Communication and the evolution of society, transl. T. McCarthy, Heinemann, London.

Habermas, J., 1993, Na-metafysisch denken, vertl. A. Middelhoek, Kok Agora, Kampen.

Habermas, J., 2008, Between naturalism and religion: Philosophical essays, transl. C. Cronin, Polity Press, Cambridge. (English translation of Zwischen Naturalismus and Religion. Philosophische Aufsätze.)

Haldane, J.B.S., 1947, What is life?, Boni and Gaer, New York, NY.

Howell, N.R., 2000, A feminist cosmology: Ecology, solidarity, and metaphysics, Humanity Books, New York, NY.

Keosian, J., 1965, The origin of life, Reinhold Publishing, New York, NY.

Labuschagné, C.J., 1991, 'Creation and the status of humanity in the Bible', in V. Brümmer (ed.), Interpreting the Universe as Creation, pp. 123-131, Pharos Kok Publishing House, Kampen.

Lennox, J.G., 2001, Aristotle's philosophy of Biology, Cambridge University Press, Cambridge.

Liedke, G., 1983, Im Bauch des Fisches: Ökologishe Theologie, Kreuz Verlag, Stuttgart.

Lindbeck, G.A., 1984, The nature of doctrine: Religion and theology in a postliberal age, The Westminster Press, Philadelphia, PA.

Maarschalk, R., 2001, 'Die Godsredes in die boek Job, ideologie en ekoteologie', ongepubliseerde D Litt et Phil Proefskrif, Dept. Bybelkunde, RAU.

McFague, S., 1993, The Body of God: An ecological theology, Fortress Press, Minneapolis, MN.

McGrath, A., 2005, Dawkins' God: Genes, memes and the meaning of life, Blackwell, Oxford.

Paley, W., 2006, Natural Theology, Oxford University Press, Oxford.

Paton, J., 1972, The moral law: Kant's groundwork of the metaphysics of morals, Hutchinson University Library, London.
Peacocke, A., 2004, Evolution: The disguised friend of faith?, Templeton Foundation Press, Philadelphia, PA.

Peters, T., 2003, Science, theology and ethics, Ashgate, Aldershot.

Popper, K., 1966, 'The open societies and its enemies', in Freie Universität Berlin, viewed 18 February 2012, from http://www.inf.fu-berlin.de/lehre/WS06/pmo/ eng/Popper-OpenSociety.pdf

Popper, K., 2000, Knowledge and the body-mind problem, Routledge, London.

Potter, S.M., 1986, 'The meaning of “Life"', in Ibiblio, viewed 27 January 2012, from http://ibiblio.org/jstrout/uploading/potter_life.html

Ridley, M., 2003, Nature via nurture, Fourth Estate, London.

Ruse, M., 2008, Charles Darwin, Blackwell Publishing, Oxford. http://dx.doi.org/ 10.1002/9781444301366

Schrödinger, E., [1944] 1967, What is life? The physical aspect of the living cell, Cambridge University Press, Cambridge.

Singer, P., 1993, Practical ethics, Cambridge University Press, Cambridge.

Singer, P., 1994, Rethinking life and death: A collapse of our traditional ethics, St. Martin's Griffin, New York, NY.

Smuts, J., [1926] 1987, Holism and evolution, N \& S House, Cape Town.

Tanner, K., 1988, God and creation in Christian theology, Blackwell, Oxford.

Taylor, B., 2010, Dark green religion, University of California Press, Berkeley, CA.

Van Huyssteen, J.W., 2006, Alone in the world? Human uniqueness in science and theology, Eerdmans, Grand Rapids, MI.

Wainwright, E.M., 2010, 'Place, power and potentiality: Reading Matthew 2:1-12 ecologically', The Expository Times 121(4).

Weber, B., 2010 'What is life? Defining life in the context of emergent complexity', in Origins of Life and Evolution of Biospheres, (abstract), vol. 40(2), viewed 19 February 2012, from http://www.springerlink.com/content/d9m181826q606482/

Weber, B., 2011, 'Life', in Stanford Encyclopedia of Philosophy, viewed 27 January 2012, from http://plato.stanford.edu/entries/life/

White, L., 1996, 'The historical roots of our ecological crisis', in This Sacred Earth: Religion, Nature, Environment, pp. 181-193, Routledge, New York, NY.

Wildman, W.J., 2009, Science and religious anthropology, Ashgate, Surrey.

Wildman, W.J., 2010, 'Distributed identity: Human beings as walking, thinking ecologies in the microbial world', in, Human Identity at the Intersection of Science, ecologies in the microbial world', in, Human Identity at the
Technology and Religion, pp. 165-178, Ashgate, Surrey.

Wilson, E.O., 2000, Sociobiology: The new synthesis, 25th Anniversary edn., The Belknap Press, Harvard, MA. 